\title{
Ground-Water Discharge from the Coastal Plain of Virginia
}

\author{
By Donna L. Richardson
}

U.S. GEOLOGICAL SURVEY

Water-Resources Investigations Report 93-4191

Prepared in cooperation with the DEPARTMENT OF ENVIRONMENTAL QUALITY WATER DIVISION

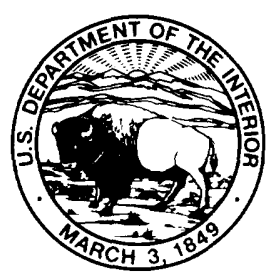

Richmond, Virginia 


\title{
U.S. DEPARTMENT OF THE INTERIOR BRUCE BABBITT, Secretary
}

\author{
U.S. GEOLOGICAL SURVEY
}

GORDON P. EATON, Director

UNITED STATES GOVERNMENT PRINTING OFFICE: 1994

Copies of this report can be purchased from:

U.S. Geological Survey

Earth Science Information Center

Open-File Reports Section

Box 25286, MS 517

Denver Federal Center

Denver, CO 80225

For additional information write to:

District Chief

U.S. Geological Survey

3600 West Broad Street

Room 606

Richmond, VA 23230 


\section{CONTENTS}

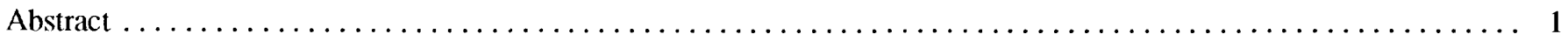

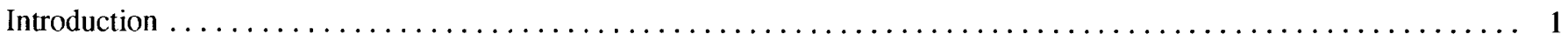

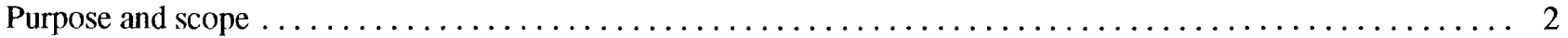

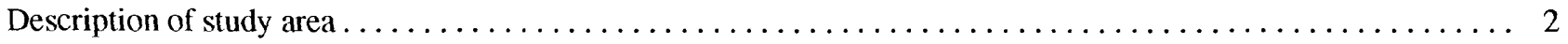

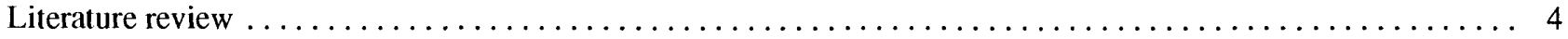

Ground-water discharge from the Coastal Plain of Virginia $\ldots \ldots \ldots \ldots \ldots \ldots \ldots \ldots \ldots \ldots \ldots \ldots \ldots \ldots \ldots \ldots$

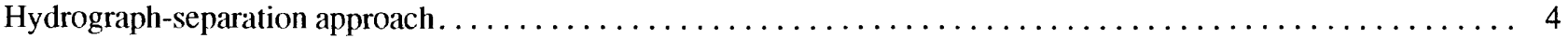

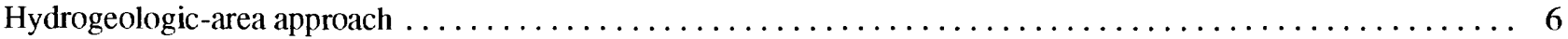

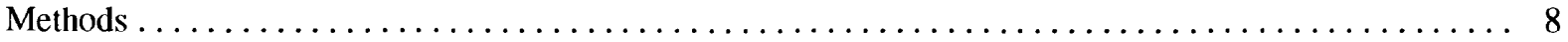

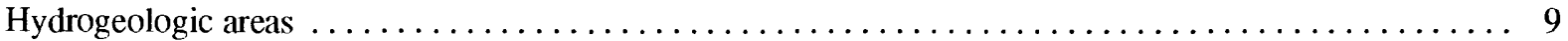

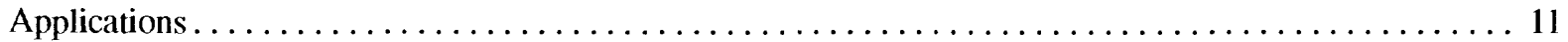

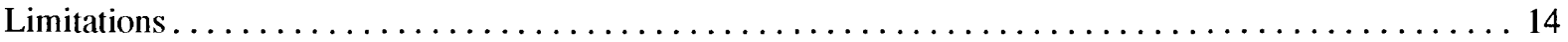

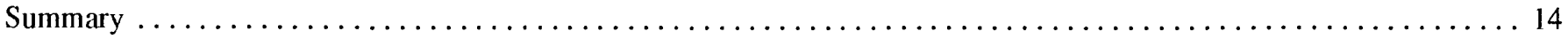

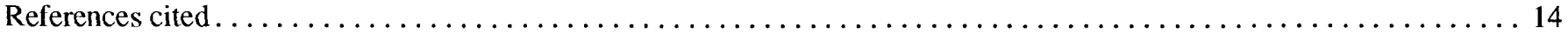

\section{PLATE}

1. Map showing hydrogeologic areas in the Coastal Plain of Virginia In pocket

\section{FIGURES}

1. Schematic showing generalized flow through the ground-water system. $\ldots \ldots \ldots \ldots \ldots \ldots \ldots \ldots \ldots \ldots \ldots$

2-6. Maps showing:

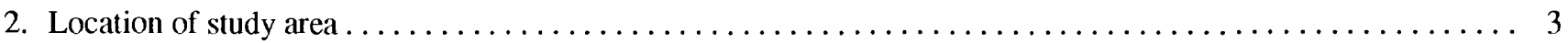

3. Location of continuous-record gaging stations used for analysis of ground-water discharge $\ldots \ldots \ldots \ldots \ldots$

4. Ratio of winter ground-water discharge to summer ground-water discharge at continuous-record gaging stations . 7

5. Hydrologic units with average annual ground-water discharge estimated using hydrogeologic-area approach. . . . 12

6. Chickahominy River subbasins with average annual ground-water discharge estimated using hydrogeologic-area

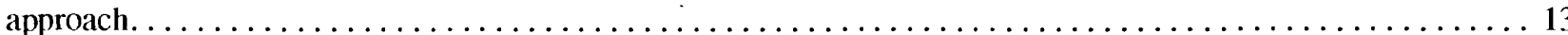

\section{TABLES}

1. Estimates of ground-water discharge at continuous-record streamflow-gaging stations in the Coastal Plain

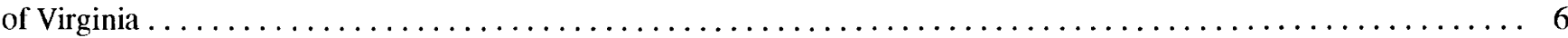

2. Hydrogeologic data used in the hydrogeologic-area approach $\ldots \ldots \ldots \ldots \ldots \ldots \ldots \ldots \ldots \ldots \ldots \ldots \ldots$

3. Hydrogeologic-area combinations examined for the hydrogeologic-area approach $\ldots \ldots \ldots \ldots \ldots \ldots \ldots \ldots$

4. Regression model for estimating average annual ground-water discharge using hydrogeologic areas in the Coastal Plain of Virginia, and values used to develop regression model, and error statistics $\ldots \ldots \ldots \ldots \ldots \ldots$

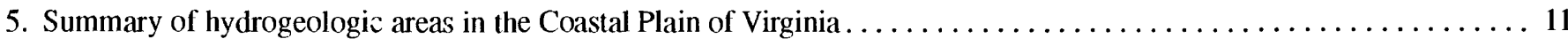


CONVERSION FACTORS AND VERTICAL DATUM

\begin{tabular}{rll}
\hline Multiply & By & To obtain \\
\hline inch (in.) & 25.40 & millimeters \\
foot $(\mathrm{ft})$ & 0.3048 & meter \\
square mile $\left(\mathrm{mi}^{2}\right)$ & 2.590 & square kilometer \\
cubic foot per second $\left(\mathrm{ft}^{3} / \mathrm{s}\right)$ & 0.02832 & cubic meter per second \\
\hline
\end{tabular}

Sea level: In this report "sea level" refers to the National Geodetic Vertical Datum of 1929-a geodetic datum derived from a general adjustment of the first-order level nets of the United States and Canada, formerly called Sea Level Datum of 1929 


\title{
Ground-Water Discharge from the Coastal Plain of Virginia
}

\author{
By Donna L. Richardson
}

\section{Abstract}

The Chesapeake Bay and other important surfacewater bodies receive ground water that discharges directly from the Coastal Plain of Virginia. This report presents estimates of the average annual ground-water discharge from the Coastal Plain of Virginia using two approaches. Average annual ground-water discharge from 16 gaged watersheds in the Coastal Plain of Virginia estimated by use of a streamflow hydrograph-separation approach ranged from 7.5 to 12.5 inches per year; the median was 10.8 inches per year. These estimates are similar to those reported by other investigators for the Coastal Plain in the nearby Delmarva Peninsula. Average annual groundwater discharge also was estimated by use of a hydrogeologic-area approach. In this approach, areas that have similar hydrogeologic characteristics are grouped and multiple regression is used to determine the relation between the hydrogeologic areas and ground-water discharge. The multiple-regression analysis indicates that ground-water discharge within the Coastal Plain of Virginia is a function of the relative areal extent of welldrained uplands and moderately well-drained uplands. On the basis of the hydrogeologic-area approach, groundwater discharge from the Coastal Plain of Virginia averages 9.9 inches per year.

\section{INTRODUCTION}

Nutrients and other chemicals released at land surface percolate through the soil and into the ground-water system. Many chemicals remain in solution and eventually discharge with the ground water to surface-water bodies, many of which are vital natural resources. The concentration of any dissolved constituent in ground water can readily be determined by analyzing water samples from suitably distributed wells; however, loads of chemical constituents transported through the groundwater system can be estimated only if the quantity of ground water that discharges to surface-water bodies is known.

The ground-water system in the Coastal Plain of Virginia consists of an interlayered sequence of aquifers and confining units. Ground-water recharge occurs primarily by the downward percolation of water through the unsaturated zone during and after a precipitation event. Most ground water that is discharged eventually contributes to streamflow (fig. 1). This contribution to streamflow from ground-water discharge is commonly referred to as base flow. Ground water in coastal areas also can discharge directly to estuaries. During steadystate conditions with no change in aquifer storage, the amount of ground-water discharge is less than the total amount of ground-water recharge because, where the water table is close to land surface, some ground water is lost to the atmosphere through evapotranspiration (fig. 1). Ground-water discharge is sometimes referred to as effective recharge because it represents the amount of recharge that is available for withdrawal from aquifers or streams. Most of the ground-water flow beneath the Coastal Plain of Virginia discharges into the Chesapeake Bay; therefore, an understanding of the ground-water component of the hydrologic system is an important part of an overall strategy for protecting the quality of water in the Bay.

Ground-water discharge is commonly estimated by use of streamflow hydrograph-separation techniques that measure base flow of gaged streams. Hydrographseparation techniques are not applicable to much of the 


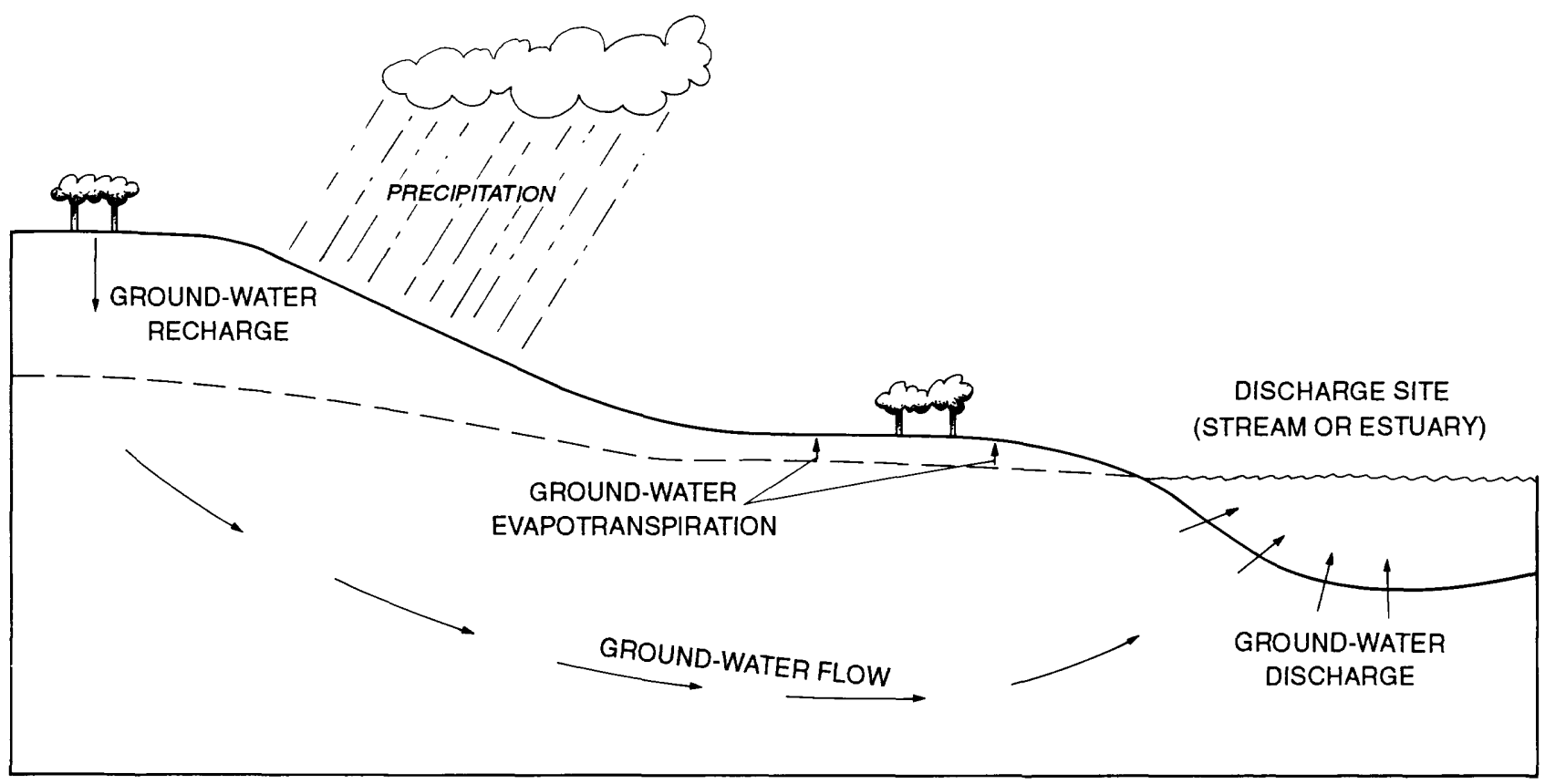

NOT TO SCALE

Figure 1. Schematic showing generalized flow through the ground-water system.

Coastal Plain of Virginia, however, because the lower reaches of most of the rivers and streams are affected by tides, and many coastal basins discharge directly to estuaries. In addition, hydrograph-separation techniques yield a single-average value of ground-water discharge from an entire watershed that can mask differences in groundwater discharge from diverse hydrogeologic terranes within the watershed. In 1991, the U.S. Geological Survey (USGS), in cooperation with the Virginia Department of Environmental Quality-Water Division, began a study to estimate average annual ground-water discharge from the Coastal Plain physiographic province of Virginia.

\section{Purpose and Scope}

This report presents estimates of average annual ground-water discharge from the Coastal Plain physiographic province of Virginia. A review of published reports provides several estimates of groundwater discharge from similar hydrogeologic settings. In this report, the annual ground-water discharge from the
Coastal Plain of Virginia is estimated using two approaches: (1) a streamflow-hydrograph-separation approach; (2) a regionalized approach based on differences in hydrogeologic characteristics. The regionalized approach classifies areas based on hydrologic and geologic data that are available for the entire Coastal Plain. Areas that have similar hydrogeologic characteristics are grouped; the groups are named "hydrogeologic areas" for the purposes of this report. The hydrogeologic areas are then used to extrapolate hydrologic data from basins for which streamflow records are available to areas where stream-flow records are not available. The report describes the techniques used and presents a map showing the hydrogeologic areas.

\section{Description of Study Area}

The study area is located within the Atlantic Coastal Plain physiographic province and includes the eastern third of Virginia (fig. 2). The area covers approximately $13,000 \mathrm{mi}^{2}$ and is bounded to the west by the Fall Line, to 


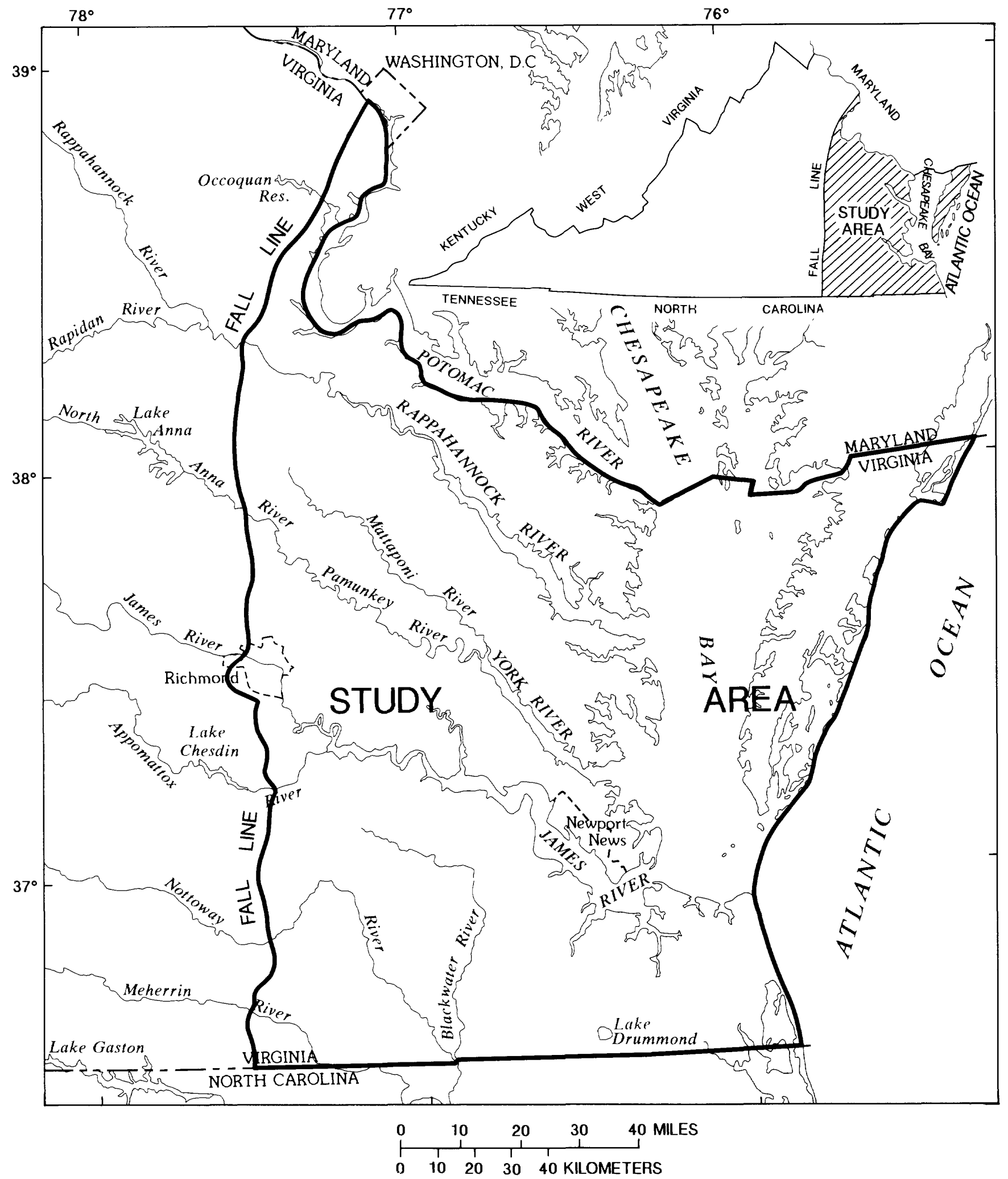

Figure 2. Location of study area. 
the north by Maryland, to the south by North Carolina, and to the east by the Chesapeake Bay and Atlantic Ocean. The area is characterized by a gently sloping land surface and a dissected lowland with a series of ocean-cut terraces. The study area is underlain predominantly by unconsolidated, interbedded sands and clays, ranging in age from Early Cretaceous to Holocene.

\section{Literature Review}

No previous studies are known to have attempted to estimate amounts of average annual ground-water discharge on a regional basis for the entire Coastal Plain of Virginia. This section summarizes several studies that have quantified average annual ground-water discharge in nearby areas within the Atlantic Coastal Plain physiographic province.

Rasmussen and Andreasen (1959) present a hydrologic budget of the Beaverdam Creek Basin-a $19.5 \mathrm{mi}^{2}$ watershed on the Delmarva Peninsula in the Maryland Coastal Plain. They developed a method to estimate average annual ground-water discharge by use of a baseflow rating curve. The base-flow rating curve was obtained by plotting the average water level in wells throughout the basin against the base flow from the streamflow hydrograph. This method was applied to average water-levels and base-flow data collected on a weekly basis during a 2-year period. The estimate for average annual ground-water discharge was $10.7 \mathrm{in} / \mathrm{yr}$, or 72 percent of the total runoff from the basin.

In a study examining base flow as an indicator of aquifer characteristics, Johnston (1971) estimated the base flow of several streams in the Coastal Plain of Delaware for a 10 -year period by use of hydrograph-separation techniques described by Riggs (1963). Average annual ground-water discharge for these streams ranged from 75 to 90 percent of total streamflow.

Cushing and others (1973), in a comprehensive study of the water resources of the Delmarva Peninsula, developed a relation between base flow and median flow for 10 streams throughout the peninsula. The relation indicated that there was little difference between estimates of annual mean base flow by hydrograph separation and estimates of annual median streamflow by analysis of daily discharge records for 1958-67. Therefore, annual median streamflows at all gaging stations in the Delmarva Peninsula were divided by drainage areas to estimate the amount of ground-water discharge per unit area. Estimated average base flow during 1958-67 in the individual gaged basins ranged from 3.5 to $16.5 \mathrm{in} / \mathrm{yr}$; estimated average base flow from the entire peninsula was estimated as $8.5 \mathrm{in} / \mathrm{yr}$ or 57 percent of the estimated total streamflow.

\section{GROUND-WATER DISCHARGE FROM THE COASTAL PLAIN OF VIRGINIA}

The quantity of water that enters and flows through the ground-water system of the Coastal Plain of Virginia is not well understood. The hydrology of such a complex regional system is a composite of subregional and local systems that have diverse characteristics. Ground-water discharge is defined as total recharge to the groundwater system minus water loss to the atmosphere through evapotranspiration. In this report, the annual groundwater discharge from the Coastal Plain of Virginia is estimated using two approaches: (1) a streamflowhydrograph-separation approach; (2) a regionalized approach based on differences in hydrogeologic characteristics.

\section{Hydrograph-Separation Approach}

A computerized streamflow-partitioning method (Rutledge, 1993) was used to estimate ground-water discharge on an annual and seasonal basis for 16 continuous-record streamflow-gaging stations in the Coastal Plain of Virginia (fig. 3). The stations were selected because they are located on unregulated streams for which at least 10 years of continuous streamflow records for the period 1970-90 are available. In addition, the stations have drainage basins that are predominantly in the Coastal Plain physiographic province. The analysis used streamflows for the 1970-90 period of record. Stations with a 20 -year period of record that included most of the 1970-90 period of record also were considered in the analysis. Stations with a shorter period of record (but no less than 10 years) were correlated to the 1970-90 period to normalize the data with respect to time (table 1).

Average annual ground-water discharge at the 16 continuous-record streamflow-gaging stations ranged from 7.51 to $12.51 \mathrm{in} / \mathrm{yr}$ with a median ground-water discharge of $10.87 \mathrm{in} / \mathrm{yr}$ (table 1). Given an estimated area for the Coastal Plain of Virginia of $8,600 \mathrm{mi}^{2}$, an estimated $6,890 \mathrm{ft} / \mathrm{s}$ of ground water discharges from the Coastal Plain of Virginia to surface water. 


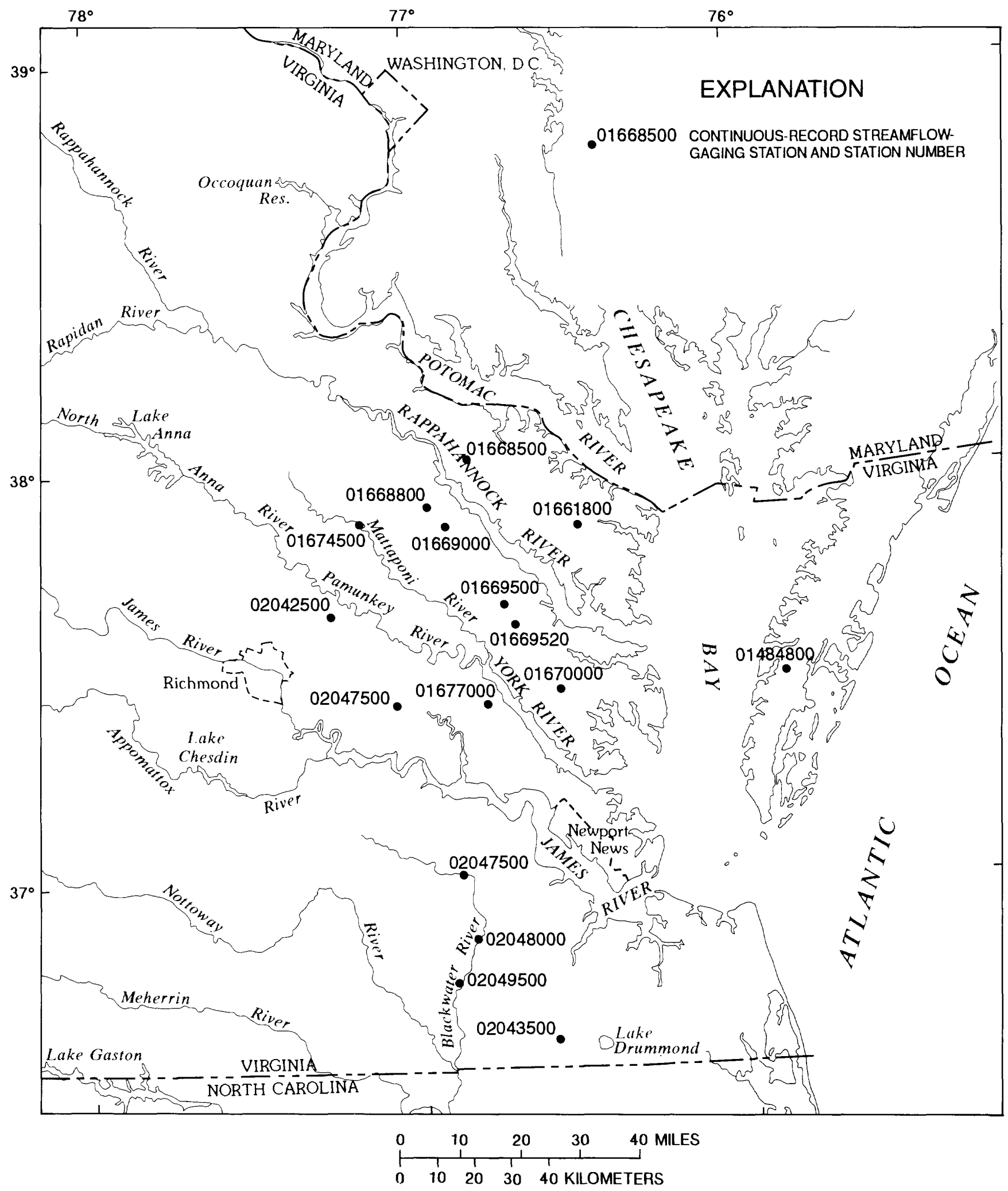

Figure 3. Location of continuous-record gaging stations used for analysis of ground-water discharge. 
Table 1. Estimates of ground-water discharge at continuous-record streamflow-gaging stations in the Coastal Plain of Virginia

[GWD, ground-water discharge: GWD as PCT, ground-water discharge as percentage of total streamflow; winter is November through March; summer is May through September, $\mathrm{mi}^{2}$, square mile; in/yr, inch per year, in., inch]

\begin{tabular}{rccccccc}
\hline $\begin{array}{c}\text { Station } \\
\text { number } \\
\text { (fig. } \mathbf{3})\end{array}$ & $\begin{array}{c}\text { Drainage } \\
\text { area } \\
\mathbf{( m i}^{\mathbf{2}} \mathbf{)}\end{array}$ & $\begin{array}{c}\text { Period of record } \\
\text { for analysis }\end{array}$ & $\begin{array}{c}\text { Annual } \\
\text { GWD } \\
\text { (in/yr) }\end{array}$ & $\begin{array}{c}\text { Annual } \\
\text { GWD as } \\
\text { PCT }\end{array}$ & $\begin{array}{c}\text { Winter } \\
\text { GWD } \\
\text { (in.) }\end{array}$ & $\begin{array}{c}\text { Summer } \\
\text { GWD } \\
\text { (in.) }\end{array}$ & $\begin{array}{c}\text { Ratio of } \\
\text { Winter GWD } \\
\text { to summer } \\
\text { GWD }\end{array}$ \\
\hline 01484800 & 1.72 & $1970-90$ & 8.08 & 72 & 5.08 & 1.59 & 3.2 \\
01661800 & 6.82 & $1967-87$ & 10.37 & 70 & 5.59 & 2.67 & 2.1 \\
01668500 & 45.6 & $1970-90$ & 10.87 & 73 & 6.00 & 2.85 & 2.1 \\
01668800 & 15.5 & $1970-87$ & 12.30 & 78 & 6.39 & 3.73 & 1.7 \\
01669000 & 28.0 & $1970-90$ & 12.51 & 79 & 6.67 & 3.50 & 1.9 \\
${ }^{1} 01669500$ & 84.9 & $1970-90$ & 10.78 & 74 & 6.42 & 2.46 & 2.6 \\
${ }^{1} 01669520$ & 108 & $1970-90$ & 11.14 & 74 & 6.34 & 2.82 & 2.2 \\
01670000 & 6.63 & $1970-89$ & 10.58 & 71 & 5.99 & 2.53 & 2.4 \\
${ }^{1} 01673550$ & 26.2 & $1970-90$ & 12.00 & 71 & 6.54 & 3.53 & 1.9 \\
01674500 & 601 & $1970-90$ & 9.72 & 65 & 5.48 & 2.34 & 2.3 \\
${ }^{1} 01677000$ & 6.29 & $1970-90$ & 11.22 & 73 & 5.57 & 3.85 & 1.4 \\
02042500 & 248 & $1970-90$ & 10.60 & 70 & 6.36 & 2.32 & 2.7 \\
${ }^{1} 02043500$ & 23.8 & $1970-90$ & 7.51 & 47 & 5.88 & .65 & 9.0 \\
02047500 & 294 & $1970-90$ & 11.01 & 69 & 7.42 & 1.64 & 4.5 \\
02048000 & 456 & $1968-88$ & 12.22 & 75 & 7.91 & 2.18 & 3.6 \\
02049500 & 617 & $1970-90$ & 11.26 & 76 & 7.18 & 2.01 & 3.6 \\
\hline
\end{tabular}

${ }^{1}$ Stations that have been extended to normalize to $1970-90$ period of record.

Ground-water conditions are not uniform throughout the Coastal Plain of Virginia and the importance of evapotranspiration in the different regions in the Coastal Plain is demonstrated in the seasonal estimates of ground-water discharge (table 1). Winter ground-water discharge was computed from streamflow data collected during November through March; discharge ranged from 5.08 to 7.91 in. Summer ground-water discharge was computed from streamfiow data collected during May through September; discharge ranged from 0.65 to 3.85 in. October and April were omitted from the seasonal calculations because they are transitional months with respect to climate in the Coastal Plain of Virginia. Ground-water discharge in the summer is lower than in the winter because of evapotranspiration during the growing season. The ratio of winter ground-water discharge divided by summer ground-water discharge is a useful indicator of the importance of evapotranspiration in the basin (table 1). The highest ratios (higher rates of evapotranspiration) occur at stations south of the James River (fig. 4).
The hydrograph-separation approach for estimating average annual ground-water discharge has limited value because only the gaged parts of the Coastal Plain of Virginia are represented. Most of the area is ungaged; therefore, results are biased toward the hydrogeologic conditions typical of the gaged areas. The results may be sufficient on a regional, "Coastal-Plain-wide" basis; however, the results are not necessarily transferable to areas where hydrogeologic conditions differ from those in the gaged basins.

\section{Hydrogeologic-Area Approach}

The rate of ground-water discharge from a basin depends largely on the physical and hydrogeologic setting. The hydrogeologic-area approach was developed to estimate average annual ground-water discharge from areas that have diverse hydrogeologic characteristics. This approach consists of developing an equation for estimating ground-water discharge that is based on the percentage of a drainage area that lies within a particular type of hydrogeologic setting (or hydrogeologic area). 


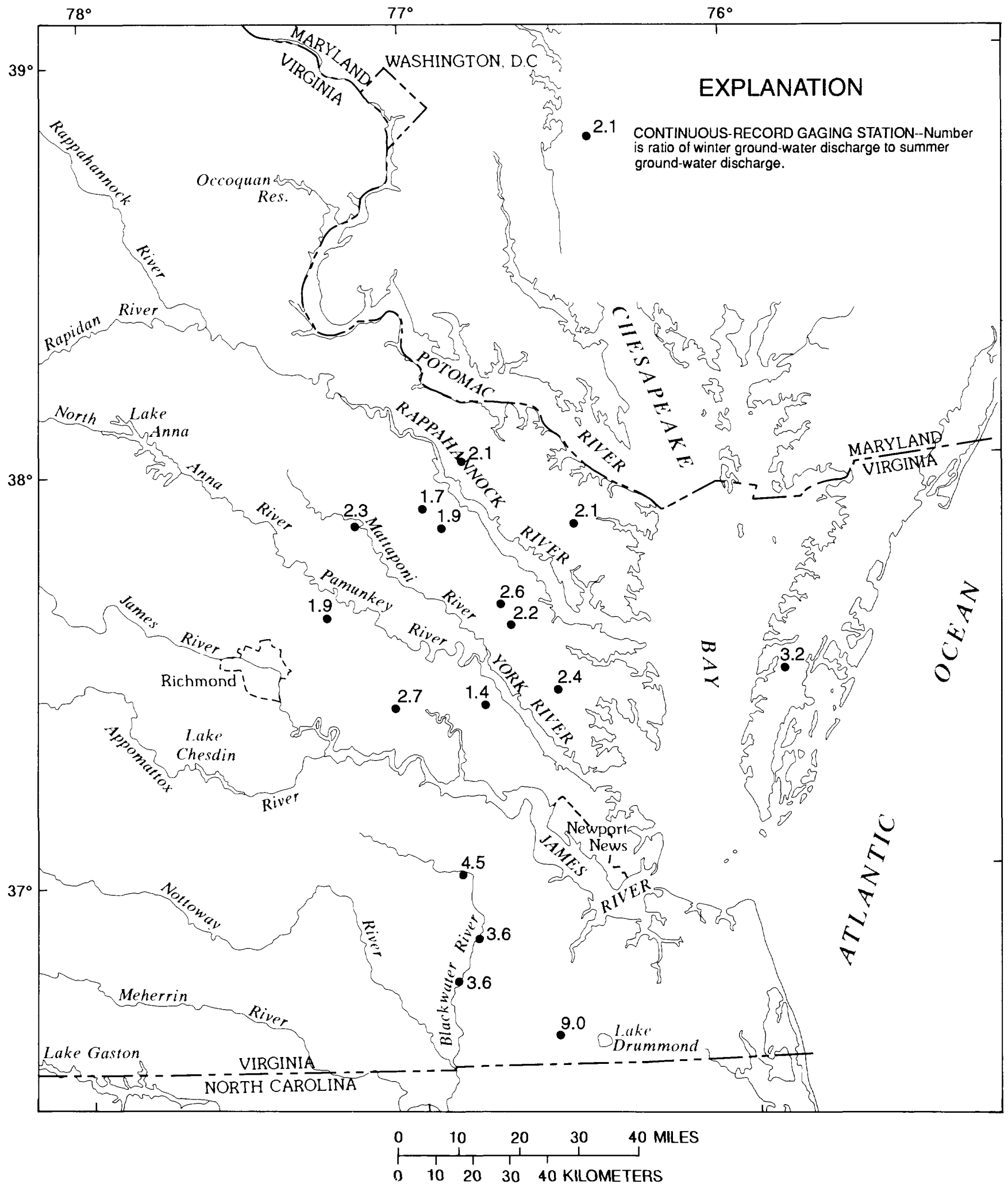

Figure 4. Ratio of winter ground-water discharge to summer ground-water discharge at continuous-record gaging stations. 
Table 2. Hydrogeologic data used in the hydrogeologic-area approach

[ft, feet; >, greater, <, less than]

\begin{tabular}{|c|c|}
\hline Type of data & Properties ${ }^{1}$ \\
\hline \multirow[t]{2}{*}{ Surficial geology $y^{2}$} & Predominantly upland ( $>80 \mathrm{ft}$ elevation) geologic units \\
\hline & Predominantly lowland ( $<80 \mathrm{ft}$ elevation) geologic units \\
\hline \multirow[t]{2}{*}{ Forest cover ${ }^{3}$} & Forested \\
\hline & Unforested (includes all other land uses) \\
\hline \multirow[t]{4}{*}{ Soil-hydrology class ${ }^{4}$} & $\begin{array}{l}\text { Class A-High infiltration rates, deep soils, well drained to excessively drained soils } \\
\text { and gravels. }\end{array}$ \\
\hline & $\begin{array}{c}\text { Class B-Moderate infiltration rates, deep and moderately deep, moderately well and } \\
\text { well-drained soils with moderately coarse textures. }\end{array}$ \\
\hline & $\begin{array}{c}\text { Class C-Siow infiltration rates, soils impede downward movement of water, } \\
\text { moderately fine and fine textures. }\end{array}$ \\
\hline & Class D-Very slow infiltration rates, clayey, high water-table soils. \\
\hline \multirow[t]{3}{*}{ Soil drainage 4} & Well drained \\
\hline & Moderately well drained \\
\hline & Poorly drained \\
\hline \multirow[t]{8}{*}{ Soil texture 4} & Sand, loamy sand, loamy-very-fine sand, very-fine sand, fine sand \\
\hline & Fine-sandy loam, sandy loam \\
\hline & Very-fine-sandy loam, loam, silt loam, silt \\
\hline & Clay loam, sandy-clay loam, silty-clay loam \\
\hline & All clays \\
\hline & Muck, mucky peat, peat \\
\hline & Unweathered bedrock \\
\hline & Fragmental material \\
\hline \multirow[t]{4}{*}{ Soil slope 4} & $0-2$ percent slope \\
\hline & $2-5$ percent slope \\
\hline & $5-10$ percent slope \\
\hline & $>10$ percent slope \\
\hline
\end{tabular}

\footnotetext{
${ }^{1}$ Properties are quantitatively expressed in the analysis as the percentage of a drainage basin covered by that property.

${ }^{2}$ Mixon and others, 1989.

${ }^{3}$ U.S. Geological Survey, 1990.

${ }^{4}$ U.S. Department of Agriculture, 1991.
}

The following section describes the methods, hydrogeologic areas, applications, and limitations of the hydrogeologic-area approach.

\section{Methods}

Hydrologic and geologic data for the Coastal Plain of Virginia were converted to digital form and combined by use of a geographic information system to produce a map that identifies areas with similar hydrogeologic characteristics. Digital hydrogeologic data that were easily obtainable for the entire Coastal Plain were used in the analysis. The types of data included surficial geology, forest cover, and soil hydrologic class, soil drainage, soil texture, and soil slope (table 2). Climatic data (precipitation and temperature) do not vary significantly within the Coastal Plain (Hayes, 1991) and were not included in the analysis.
The following iterative procedure was used to select the final combination of data for the hydrogeologic areas: 1. The hydrogeologic data were combined into preliminary hydrogeologic areas using a geographic information system. Because several hydrogeologic properties overlap one another, many spatially distinct hydrogeologic areas characterized by two or more properties could be defined - for example, steep-sloped uplands and well-drained, heavily forested areas (table 2).

2. Data from the 16 continuous-record streamflow-gaging stations were used to develop multiple-linear regression equations. The response variable was average annual ground-water discharge estimated by streamflow-hydrograph separation. The explanatory variables were the percentage of each preliminary-hydrogeologic area in the basin. 
3. The best regression equation for that preliminaryhydrogeologic area was selected by maximizing the adjusted coefficient of determination $\left(R^{2} a\right)^{1}$. The multiple-regression models were limited to those with one or two explanatory variables in the final regression equation. Because only 16 estimates of ground-water discharge were available to develop the regression equation, the statistical validity of the regression equation is questionable for more than two explanatory variables.

This procedure was repeated for several preliminaryhydrogeologic areas developed from various combinations of hydrogeologic data (table 3). Thirteen different combinations were chosen as being potentially important for a hydrogeologic understanding of the areas. The combinations were limited to one or two types of data to reduce the number of potential hydrogeologic areas. The combination that resulted in the regression equation that best explained the variation in the ground-water-discharge data was selected as the final hydrogeologic-area map. Diagnostics used to determine the best regression equations included the adjusted coefficient of determination, residual errors, PRESS statistic, ${ }^{2}$ Mallow's $\mathrm{Cp}^{3}$, and points of leverage ${ }^{4}$ and influence ${ }^{5}$ (Helsel and Hirsch, 1992).
Table 3. Hydrogeologic-area combinations examined for the hydrogeologic-area approach

\begin{tabular}{|c|c|c|c|c|c|c|c|c|c|c|c|c|c|}
\hline \multirow[b]{2}{*}{ Type of data } & \multicolumn{13}{|c|}{ Combinations of data } \\
\hline & 1 & 2 & 3 & 4 & 5 & 6 & 7 & 8 & 9 & 10 & 11 & 12 & 13 \\
\hline Surficial geology & $x$ & & & & & & & $x$ & & $x$ & & $x$ & \\
\hline Forest cover & & $x$ & & & & & & & $x$ & & $x$ & $x$ & \\
\hline Soil-hydrology class & & & $x$ & & & & $x$ & $x$ & & & & & $x$ \\
\hline Soil drainage & & & & $x$ & & & & & & $x$ & $x$ & & $x$ \\
\hline Soil texture & & & & & $x$ & & & & & & & & \\
\hline Soil slope & & & & & & $x$ & $x$ & & $x$ & & & & \\
\hline
\end{tabular}

Geology (Mixon and others, 1989) and soil drainage (U.S. Department of Agriculture, 1991) are the hydrogeologic-data elements used to produce the final map (pl. 1). The hydrogeologic areas presented in this report are a preliminary classification based on the available data; the classification could be refined with additional data. The regression equation (table 4 ) is an example of the results of a regionalized method for estimating average annual ground-water discharge; it is not intended to represent a complete understanding of all the factors that could affect ground-water discharge. The regression equation (table 4) can be used with the map of hydrogeologic areas (pl. 1) to estimate average annual ground-water discharge for any area in the Coastal Plain of Virginia, regardless of whether the area is gaged or ungaged.

\section{Hydrogeologic Areas}

The Coastal Plain of Virginia was classified into six hydrogeologic areas (1) well-drained uplands, (2) moderately well-drained uplands, (3) poorly drained uplands, (4) well-drained lowlands, (5) moderately welldrained lowlands, and (6) poorly drained lowlands (pl. 1, table 5). The reader is referred to U.S. Department of Agriculture (1991) and Mixon and others (1989) for additional details on the soil and geologic characteristics, respectively.

Uplands are defined for this report as geologic units located primarily at elevations greater than $80 \mathrm{ft}$ above sea level. The well-drained uplands constitute 36 percent of the entire Coastal Plain of Virginia and are characterized by soils that transmit water readily. The predominant geologic formations in the well-drained uplands are the Windsor Formation, the Bacons Castle Formation, and the formations of the Chesapeake Group. The moderately well-drained uplands constitute 13 percent of the Coastal 
Table 4. Regression model for estimating average annual ground-water discharge using hydrogeologic areas in the Coastal Plain of Virginia, and values used to develop regression model, and error statistics

[Values for equations are in inches per year, \%WDU is percentage of well-drained uplands; \%MWDU is percentage moderately well-drained uplands; $r^{2}$ is coefficient of determination; in/yr is inches per year]

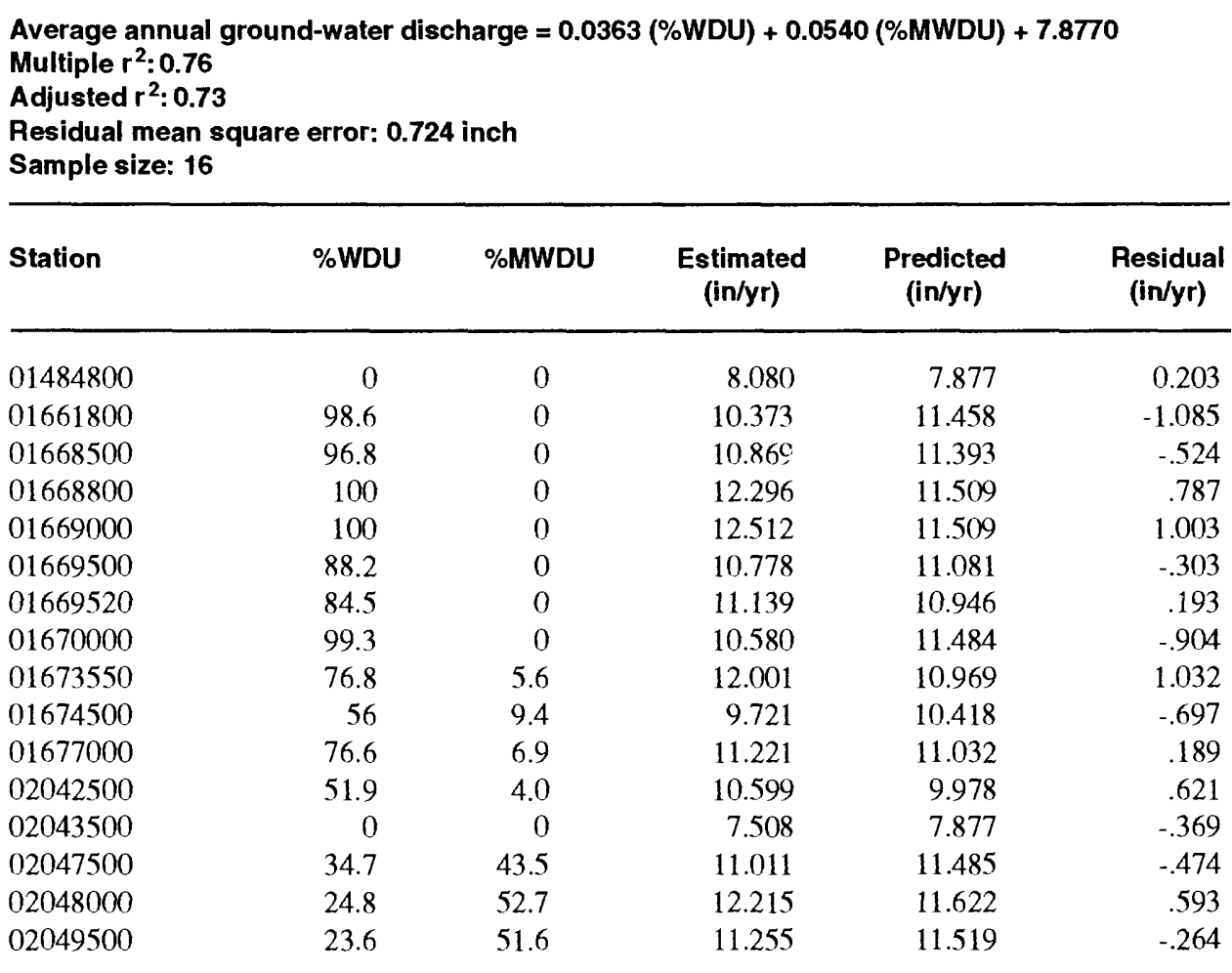

Plain of Virginia and are characterized by soils that drain somewhat slowly during parts of the year. The predominant geologic formations in the moderately well-drained uplands are the Windsor and Bacons Castle Formations, where those formations exist primarily south of the James River. There are few poorly drained uplands in the Coastal Plain of Virginia ( 2 percent). The poorly drained soils transmit water slowly enough that the soil is wet at shallow depths and remains wet for much of the year. The Windsor and Bacons Castle Formations are the predominant geologic formations. The most common geomorphic setting for the upland units is flat-lying plains.

Lowlands are defined for this report as geologic units located primarily at elevations between 0 and $80 \mathrm{ft}$ above sea level. The well-drained lowlands constitute 13 percent of the Coastal Plain of Virginia and consist of soils that transmit water readily. The predominant geologic formations in the well-drained lowlands are the
Shirley Formation, the Sedgefield Member of the Tabb Formation, and the formations of the Chesapeake Group. The common geomorphic settings are stream valleys, alluvium, and terraces. The moderately well-drained lowlands constitute 16 percent of the Coastal Plain of Virginia and are characterized by soils that drain somewhat slowly during parts of the year. The predominant geologic formations in the moderately well-draincd lowlands are the Charles City Formation, the Shirley Formation, and the Sedgefield Member of the Tabb Formation. Terraces are the most common geomorphic setting. The remainder of the Coastal Plain of Virginia (20 percent) is classified as poorly drained lowlands. The poorly drained soils transmit water slowly enough that the soil is wet at shallow depths and remains wet for much of the year. The predominant geologic formation is the Tabb Formation, and the common geomorphic settings are alluvium, terraces, barriers, marshes, and swamps. 
Table 5. Summary of hydrogeologic areas in the Coastal Plain of Virginia

[>, greater than; <, less than]

\begin{tabular}{|c|c|c|c|c|c|}
\hline $\begin{array}{l}\text { Hydrogeologic } \\
\text { area }\end{array}$ & $\begin{array}{l}\text { Percentage } \\
\text { of } \\
\text { Virginia } \\
\text { Coastal } \\
\text { Plain }\end{array}$ & $\begin{array}{l}\text { Elevation } \\
\text { (in feet) }\end{array}$ & $\begin{array}{c}\text { Soil } \\
\text { drainage }\end{array}$ & $\begin{array}{l}\text { Predominant } \\
\text { geologic } \\
\text { formations }\end{array}$ & $\begin{array}{l}\text { Geomorphic } \\
\text { settings of } \\
\text { predominant } \\
\text { geologic } \\
\text { formations }\end{array}$ \\
\hline Well-drained upland & 36 & $>80$ & Water is removed from soil readily. & $\begin{array}{l}\text { Windsor Formation } \\
\text { Bacons Castle Formation } \\
\text { Chesapeake Group }\end{array}$ & Plains \\
\hline Moderately well-drained & 13 & $>80$ & $\begin{array}{l}\text { Water is removed from upland soil } \\
\text { somewhat slowly during some } \\
\text { periods of the year. }\end{array}$ & $\begin{array}{l}\text { Windsor Formation } \\
\text { Bacons Castle Formation }\end{array}$ & $\begin{array}{l}\text { Plains, fluvial-estuarine } \\
\text { terraces }\end{array}$ \\
\hline Poorly drained upland & 2 & $>80$ & $\begin{array}{l}\text { Water is removed from soil slowly } \\
\text { enough that soil is wet at shallow } \\
\text { depths periodically during the } \\
\text { growing season or remains wet for } \\
\text { long periods of the year. }\end{array}$ & $\begin{array}{l}\text { Windsor Formation } \\
\text { Bacons Castle Formation }\end{array}$ & Plains \\
\hline Well-drained lowland & 13 & $<80$ & Water is removed from soil readily. & $\begin{array}{l}\text { Chesapeake Group } \\
\text { Shirley Formation } \\
\text { Sedgefield member of } \\
\text { Tabb Formation }\end{array}$ & $\begin{array}{l}\text { Stream valleys, alluvium, } \\
\text { and terraces }\end{array}$ \\
\hline Moderately well-drained & 16 & $<80$ & $\begin{array}{l}\text { Water is removed from lowland } \\
\text { soil somewhat slowly during some } \\
\text { periods of the year. }\end{array}$ & $\begin{array}{l}\text { Charles City Formation } \\
\text { Shirley Formation } \\
\text { Sedgefield member of } \\
\text { Tabb Formation }\end{array}$ & Terraces \\
\hline Poorly drained lowland & 20 & $<80$ & $\begin{array}{l}\text { Water is removed from soil slowly } \\
\text { enough that soil is wet at shallow } \\
\text { depths periodically during the } \\
\text { growing season or remains wet for } \\
\text { long periods of the year. }\end{array}$ & Tabb Formation & $\begin{array}{l}\text { Terraces, alluvium, barriers, } \\
\text { marshes, and swamps }\end{array}$ \\
\hline
\end{tabular}

\footnotetext{
${ }^{1}$ U.S. Department of Agriculture, 1991

${ }^{2}$ Mixon and others, 1989
}

\section{Applications}

The regression equation (table 4 ) and the map of hydrogeologic areas (pl. 1) can be used to estimate average annual ground-water discharge for any region of interest in the Coastal Plain of Virginia. The equation to estimate average annual ground-water discharge when applied to the entire Coastal Plain of Virginia is solved by substituting the percentages of well-drained uplands and moderately well-drained uplands listed in table 5 . The amount of ground-water discharge from the entire Coastal Plain of Virginia is estimated to be $9.9 \mathrm{in} / \mathrm{yr}$ or $6,270 \mathrm{ft}^{3} / \mathrm{s}$, given an estimated recharge area of $8,600 \mathrm{mi}^{2}$.

As an additional application of the hydrogeologicarea approach, the Coastal Plain of Virginia was divided into its hydrologic units (U.S. Geological Survey, 1974). Average annual ground-water discharge from the Coastal Plain parts of each of the hydrologic units was estimated by use of the regression equation; several of the hydrologic units include areas outside of the Coastal Plain, which were not incorporated into the estimate. The average annual ground-water discharge from the Coastal Plain parts of the hydrologic units ranged from 7.9 to $11.1 \mathrm{in} / \mathrm{yr}$ (fig. 5). Hydrologic units located along major rivers and along the Atlantic coast have slightly lower discharge estimates than the more inland units. The lower estimates reflect the large percentage of lowlandhydrogeologic areas in alluvial and coastal environments.

The hydrogeologic-area approach also was applied to the Chickahominy River Basin located in the central part of the Coastal Plain of Virginia. The Chickahominy River is the major water supply for the Newport News metropolitan area. For the purposes of this example, most of the Chickahominy River Basin was divided into subbasins to illustrate the changes in ground-water discharge that occur in areas with different hydrogeologic characteristics. Average annual ground-water-discharge estimates for the subbasins estimated by use of the hydrogeologicarea approach ranged from 8.7 to $11.6 \mathrm{in} / \mathrm{yr}$ (fig. 6). Generally, estimates of ground-water discharge from 


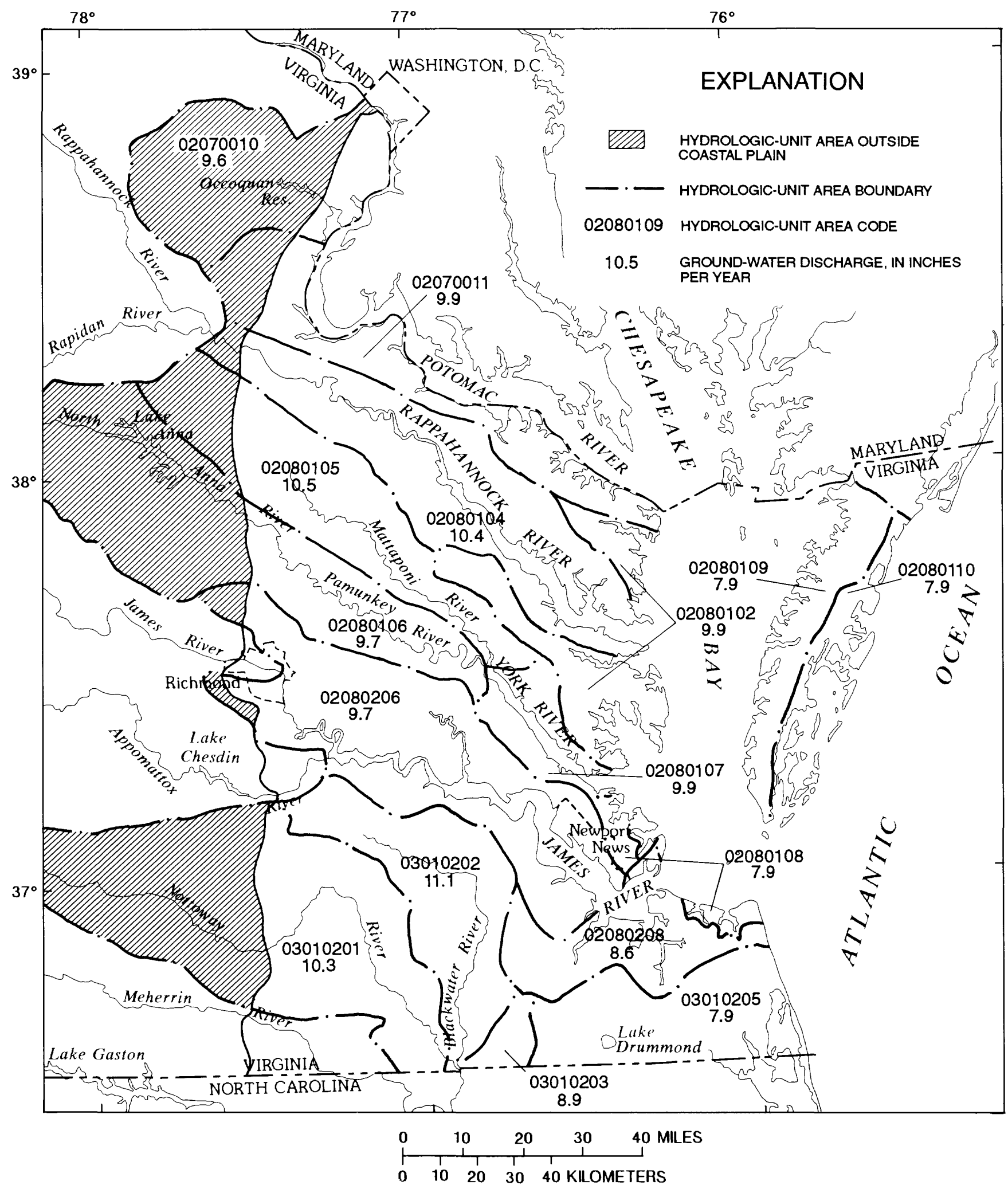

Figure 5. Hydrologic units with average annual ground-water discharge estimated using hydrogeologic-area approach. 


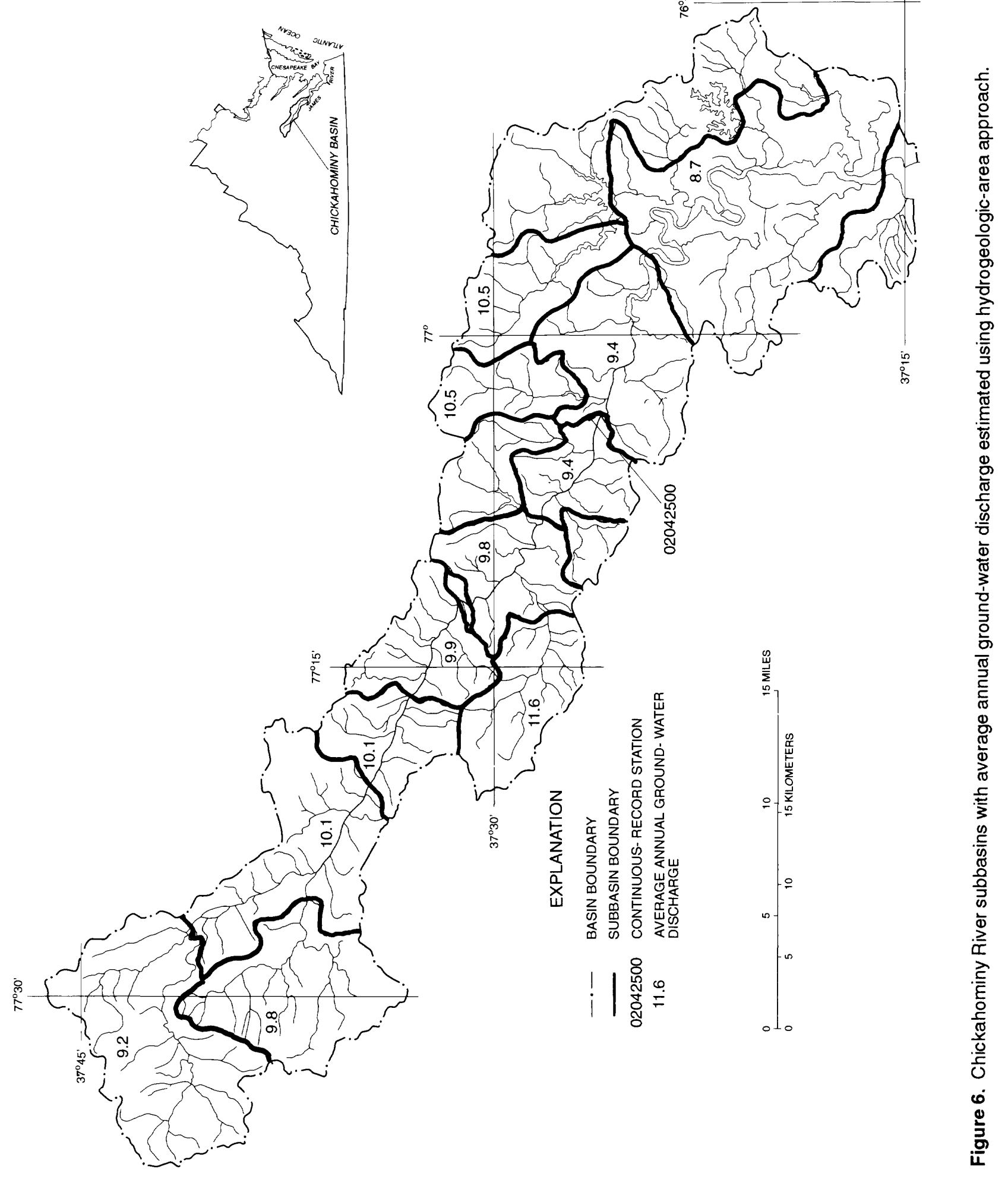


subbasins of tributaries to the Chickahominy are slightly larger than estimates of ground-water discharge from subbasins along the main stem of the Chickahominy.

The hydrogeologic-area approach presented in this report estimates ground-water discharge from regional areas of diverse hydrogeologic characteristics; however, other regional ground-water questions (for example, nutrient and pesticide loads, wetiands processes, and bestmanagement practices) could be addressed by use of this same approach. Data-collection efforts could be minimized by only collecting data that are representative of the hydrogeologic areas. In addition, results from sitespecific studies could be applied on a regional scale to those areas having similar hydrogeologic characteristics.

\section{Limitations}

The application of the hydrogeologic-area approach was limited by the amount of ground-water-discharge data that were available to develop the regression models. Only 16 estimates of ground-water discharge based on data from continuous-record streamflow-gaging stations were available to develop the regression equation; therefore, the statistical validity of the regression equation is questionable for more than two explanatory variables. Estimates of ground-water discharge based on data from partial-record sites correlated to long-term streamflowgaging stations were not used because only extremely low flows (far below mean-annual base flow) were available for the correlation. Additional ground-water-discharge estimates are needed to improve the confidence in the correlation. Application of the hydrogeologic-area approach also was limited because ground-waterdischarge estimates are based only on streamflow data. The approach assumes that the environmental characteristics that control discharge directly to estuaries are the same as those that control discharge to streams.

\section{SUMMARY}

The Chesapeake Bay and other important surfacewater bodies receive ground water that discharges directly from the Coastal Plain of Virginia. This report presents estimates of the average annual ground-water discharge from the Coastal Plain of Virginia by two different approaches.

A hydrograph-separation approach was used to estimate average annual ground-water discharge from daily streamflows at each of 16 continuous-record streamflow-gaging stations in basins predominantly in the Coastal Plain of Virginia. Average annual ground-waterdischarge estimates at the 16 stations ranged from 7.5 to $12.5 \mathrm{in} / \mathrm{yr}$, having a median estimate of $10.8 \mathrm{in} / \mathrm{yr}$.

A hydrogeologic-area approach for estimating average annual ground-water discharge was developed to evaluate a regional area with diverse hydrogeologic characteristics. This approach combines hydrologic and geologic data to produce a map of areas that have similar hydrogeologic characteristics. A regression equation relating ground-water discharge (estimated from hydrograph separation) to the percentages of the various types of hydrogeologic areas was developed to estimate average annual ground-water discharge from any region of interest in the Coastal Plain of Virginia. Based on this approach, an estimated $9.9 \mathrm{in} / \mathrm{yr}$ of ground water discharges from the entire Coastal Plain of Virginia. The method also was applied to the hydrologic units in the Coastal Plain of Virginia and subbasins in the Chickahominy River Basin. Estimated ground-water discharge for the parts of the hydrologic units in the Coastal Plain of Virginia ranged from 7.9 to $11.1 \mathrm{in} / \mathrm{yr}$. Estimated ground-water discharge from the subbasins in the Chickahominy River Basin ranged from 8.7 to $11.6 \mathrm{in} / \mathrm{yr}$. The lower estimates correspond to basins that have large proportions of poorly drained hydrogeologic areas typical of alluvial and coastal environments.

\section{REFERENCES CITED}

Cushing, E.M., Kantrowitz, I.H., and Taylor, K.R., 1973, Water resources of the Delmarva Peninsula: U.S. Geological Survey Professional Paper 822, 58 p.

Hayes, D.C., 1991, Low-flow characteristics of streams in Virginia: U.S. Geological Survey Water-Supply Paper 2374, $69 \mathrm{p}$.

Helsel, D.R., and Hirsch, R.M., 1992, Statistical methods in water resources: New York, Elsevier Science Publishers, p. 295-319.

Johnson, R.H., 1971, Base flow as an indicator of aquifer characteristics in the Coastal Plain of Delaware: U.S. Geological Survey Professional Paper 750-D, p. D212D215.

Mixon, R.B., Berquist, C.R., Jr., Newell, W.L., and Johnson, G.H., 1989, Geologic map and generalized cross sections of the Coastal Plain and adjacent parts of the Piedmont, Virginia: U.S. Geological Survey Miscellaneous Investigations Map I-2033, 2 sheets, scale 1:250,000. 
Rasmussen, W.C., and Andreasen, G.E., 1959, Hydrologic budget of the Beaverdam Creek basin, Maryland: U.S. Geological Survey Water-Supply Paper 1472, 106 p.

Riggs, H.C., 1963, The base-flow recession curve as an indicator of ground water: International Association of Scientific Hydrology Pub. 63, p. 352-363.

Rutledge, A.T., 1993, Computer programs for describing the recession of ground-water discharge and for estimating mean ground-water recharge and discharge from streamflow records: U.S. Geological Survey Water-Resources Investigations Report 93-4121, 45 p.

U.S. Department of Agriculture, 1991, State soil geographic data base (STATSGO)—Data users guide: Soil

Conservation Service Miscellaneous Publication 1492, 88 p.

U.S. Geological Survey, 1974, Hydrologic unit map-1974, State of Virginia, 1 sheet, scale 1:250,000.

U.S. Geological Survey, 1990, Landuse landcover 1:250,000 scale: National Mapping Program Technical Instructions, Data Users Guide 4. 